University of Chicago Law School

Chicago Unbound

Journal Articles

Faculty Scholarship

1999

\title{
The Scope of Criminal Forfeiture Under RICO: The Appropriate Definition of Proceeds
}

Anup Malani

Follow this and additional works at: https://chicagounbound.uchicago.edu/journal_articles

Part of the Law Commons

\section{Recommended Citation}

Anup Malani, "The Scope of Criminal Forfeiture Under RICO: The Appropriate Definition of Proceeds," 66 University of Chicago Law Review 1289 (1999).

This Article is brought to you for free and open access by the Faculty Scholarship at Chicago Unbound. It has been accepted for inclusion in Journal Articles by an authorized administrator of Chicago Unbound. For more information, please contact unbound@law.uchicago.edu. 


\title{
The Scope of Criminal Forfeiture Under RICO: The Appropriate Definition of "Proceeds"
}

\author{
Anup Malani
}

Congress enacted the Racketeer Influenced and Corrupt Organizations ("RICO") statute in 1970 to limit the infiltration of organized crime into legitimate business organizations. ${ }^{2}$ To this end, RICO criminalizes participation in a "pattern of racketeering activity" in the context of an "enterprise." A pattern of racketeering activity consists of at least two federal or state crimes, as specified in the statute, ${ }^{4}$ that have "similar purposes, results, participants, victims, or methods of commission"5 and "amount to or pose a threat of continued criminal activity." An enterprise is broadly defined as "any individual, partnership, corporation, association, or other legal entity, and any union or group of individuals associated in fact although not a legal entity." The context of which RICO speaks is where, through the commission of racketeering activity, the defendant "directly or indirectly invested in, or maintained an interest in, or participated in" the enterprise. $^{8}$

Congress put teeth into the RICO prohibition by creating civil and criminal penalties designed to make any commingling of

$\dagger$ B.S.F.S. 1992, Georgetown University; AM. (Economics) 1996, The University of Chicago; Ph.D. (Economics) Candidate 2000, J.D. Candidate 2000, The University of Chicago.

1 RICO was enacted as Title IX of the Organized Crime Control Act of 1970, Pub L No 91-452, 84 Stat 922, 941, codified as amended at 18 USC $\S \S 1961-68$ (1994).

2 See United States $v$ Turkette, 452 US 576, 591 (1981).

318 USC $\S 1962$. For an explanation of the elements of a RICO offense, see Bridget Allison, et al, Racketeer Influenced and Corrupt Organizations, 35 Am Crim L Rev 1103, 1107-30 (1998).

4 18 USC § 1961(1), (5). See Allison, et al, 35 Am Crim L Rev at 1107-08 (cited in note 3) (laying out the "broad assortment of state and federal crimes" that constitutes racketeering activity).

S Sedima, S.P.R.L. v Imrex Co, Inc, 473 US 479, 496 n 14 (1985), citing the former 18 USC § 3575(e) (1982) (providing for increased sentences for dangerous special offenders), repealed by the Sentencing Reform Act of 1984, Pub L No 98-473, § 212(a)(1)-(2), 98 Stat 1837, 1987 (1984). The relatedness prong was ratified by H.J., Inc $v$ Northwestern Bell Telephone Co, which cited the (by then) repealed Section 3575(e). 492 US 229, 239 (1989).

- H.J., Inc $v$ Northwestern Bell Telephone Co, 492 US at 239.

718 USC § 1961(4).

- Allison, et al, 35 Am Crim L Rev at 1107 (cited in note 3). 
organized crime and legitimate business unprofitable for the racketeer. The purpose of the penalties is to force the racketeer to disgorge her ill-gotten gains. " The Attorney General or "any person injured in his business or property by reason of" a RICO violation may bring a civil forfeiture action to limit investments in RICO enterprises. ${ }^{10}$ The scope of civil forfeiture includes divestiture, restrictions on further investment, and dissolution or reorganization of the enterprise. ${ }^{11}$ The government may also criminally prosecute and punish violators. ${ }^{12}$ Defendants may receive prison sentences separate from, but in addition to, sentences for the individual acts that constitute a pattern of racketeering. ${ }^{13}$ Furthermore, and most relevant to the purpose of this Comment, defendants are subject to a criminal fine and forfeiture of their "interests" in and "proceeds" from participation in a RICO enterprise. ${ }^{14}$

Before 1984, Section 1963 subjected only "interests" in a RICO enterprise to criminal forfeiture. In Russello $v$ United States ${ }^{15}$ the Supreme Court indicated that these "interests" were not limited to a defendant's property or ownership interests in the enterprise, but could include the "profits or proceeds" from the enterprise. ${ }^{16}$ However, the Court did not resolve "any ambiguity that might be inherent in [those] terms."17 Congress, seeking to codify the result in Russello and make clear that not just profits, but also proceeds, are subject to seizure by the government, ${ }^{18}$ amended Section 1963 to add subsection (a)(3), authorizing the forfeiture of "proceeds" from racketeering activity. ${ }^{19}$ While

- Russello v United States, 464 US 16, 28 (1983).

18 USC $\$ 1964$.

"Id.

1218 USC $\$ 1963$ (a). The full text of this section is contained in note 29.

13 See Allison, et al, 35 Am Crim L Rev at 1149-50 \& n 357 (cited in note 3).

1418 USC $\S 1963$ (a). This Comment does not explore the relationship between Section 1963(a)(3) and "interests" forfeiture in Section 1963(a)(1)-(2) beyond noting that the latter definitely includes a defendant's ownership or property interests in an enterprise. The addition of "proceeds" to Section 1963 covers any other assets subject to forfeiture under the rubric of "interests." See text accompanying notes 15-19.

15464 US 16 (1983).

${ }^{16}$ Id at 20-28 (interpreting pre-1984 Section 1963 to allow for forfeiture of "interests" to reach profits earned as well as property interests in business assets).

${ }^{17}$ Id at 29 n 3.

${ }^{18}$ Comprehensive Crime Control Act of 1984, S Rep No 98-225, 98th Cong, 2d Sess, reprinted in 1984 USCCAN 3382.

${ }^{19}$ Comprehensive Forfeiture Act of 1984, $\S 302$, Pub L No 98.473, 98 Stat 1837, 2040, codified at 18 USC $\S 1963$. The complete text of Section 1963(a) is contained in note 29. For a thorough account of the legislative history behind the amendment of RICO's criminal forfeiture provisions, see generally Karla R. Spaulding, "Hit Them Where it Hurts": RICO Criminal Forfeitures and White Collar Crime, 80 J Crim L \& Criminol 197 (1989). 
Congress clarified that it used "proceeds" instead of "profits" in Section 1963(a)(3) to "alleviate the unreasonable burden on the government of proving net profits, ${ }^{20}$ Congress did not resolve two issues. First, if proceeds are not just net profits, what exactly are they? Second, if net profits can be proven by the defendant or the court without burdening the government, should courts require forfeiture of only net profits? ${ }^{21}$ These questions are the focus of this Comment.

The Courts of Appeals are split over the proper interpretation of the term "proceeds."22 The Seventh Circuit holds that proceeds are only "net profits," or total revenues minus both fixed and marginal costs. ${ }^{23}$ The Second Circuit ${ }^{24}$ and a lower court in the Third Circuit $t^{25}$ have held that proceeds are "gross profits"-

${ }^{20} \mathrm{~S}$ Rep No 98-225 at 199 (cited in note 18 ).

${ }^{21}$ This second question really asks whether alleviating an accounting burden on the prosecutor is the only motive for allowing the forfeiture of more than net profits.

${ }^{22}$ None of the cases directly answers both questions about the meaning of "proceeds." Instead, they address only the first question-what exactly "proceeds" ought to consist of-and not the second question concerning the burden on prosecutors vis-à-vis defendants and courts in refining a forfeiture order.

${ }^{2}$ United States $v$ Masters, 924 F2d 1362, 1369-70 (7th Cir 1991). The case law uses the term "direct cost" to indicate marginal cost and the term "overhead" to indicate fixed cost.

${ }^{24}$ United States $v$ Lizza Industries, Inc, $775 \mathrm{~F} 2 \mathrm{~d}$ 492, 497-99 (2d $\left.\mathrm{Cir} 1985\right)$. Lizza arose before Congress added Section 1963(a)(3) to RICO in 1984. However, it came on the heels of Russello, which found that Section 1963(a)(2) interests could include proceeds and profits, a determination the 1984 amendments codified. See Russello, 464 US at 20-28; S Rep No 98-225 at 199 (cited in note 18).

${ }^{5}$ United States v Milicia, 769 F Supp 877, 888 (E D Pa 1991), appeal dismissed, 961 F2d 1569 (3d Cir 1992). Technically, Milicia is a case under the Continuing Criminal Entexprise ("CCE") statute, not the RICO statute. However, the court's reasoning in that case is relevant to the debate here. First, the text of the criminal forfeiture provisions of RICO is substantially similar to that of CCE. Comprehensive Drug Abuse Prevention and Control Act ("CDAPCA") of 1970, Pub L No 91-513, 84 Stat 1236, codified as amended at 21 USC $\$ 853$ (1994). CCE imposes forfeiture on all defendants convicted of drug felonies: "Any person convicted of a violation ... . shall forfeit to the United States ... (1) any property constituting, or derived from, any proceeds the person obtained, directly or indirectly, as the result of such violation." 21 USC $\S 853(\mathrm{a})$.

In fact, Congress amended the criminal forfeiture provisions of RICO and CCE in the same bill, the Comprehensive Crime Control Act of 1984 ("CCCA"). CCCA amended CDAPCA and RICO in Title III, Sections 303 and 302, respectively, to authorize forfeiture of proceeds from prohibited activity. Congress has acknowledged the similarity of wording and purpose in the two statutes. S Rep No 98-225 at 209, 211 (cited in note 18) (noting that the amendments were designed such that CCE Section 853(a) "is, in nearly all respects, identical to the RICO criminal forfeiture statute as amended" and indicating that '[t]he reasons for using the term 'proceeds' to define this type of property were discussed supra in the context of the amendments to the RICO criminal forfeiture provisions").

Courts generally construe RICO and CCE forfeiture provisions similarly. See United States v Garcia-Guizar, 160 F3d 511, 528 (9th Cir 1998); United States v McHan, 101 F3d 1027, 1042 (4th Cir 1996), cert denied, 520 US 1281 (1997); United States $v$ Libretti, 38 F3d 523, 528 n 6 (10th Cir 1994), affd, 516 US 29 (1995); United States $v$ Crosby, 20 F3d 480, 483-84 (DC Cir 1994); United States v South Half of Lot 7 and Lot 8, Block 14, 
total revenues minus marginal costs, but not fixed costs. The First, Fourth, and Eighth Circuits have adopted an expansive interpretation-"gross revenues," or all revenues from an activity without subtracting any costs, fixed or marginal. ${ }^{26}$ Finally, although the D.C. Circuit has rejected the Seventh Circuit's net profits approach, it has not specifically chosen any other definition. ${ }^{27}$ Most circuits that have examined the scope of proceeds subject to criminal RICO forfeiture acknowledge their disagreement. $^{28}$

This Comment has four parts. Part I shows that neither the statutory text nor the legislative history of RICO resolves the ambiguity in the definition of "proceeds." It also argues that the rule of lenity does not require a net profits definition and indeed may not apply at all to RICO criminal forfeitures. Part II proposes a definition of proceeds that would promote the congressional purposes underlying RICO. Part III illustrates that this definition is consistent with the actual outcomes of controlling cases from nearly every circuit, regardless of their nominally different definitions of the term. Finally, Part IV examines the prudential and constitutional limitations on proceeds forfeiture.

Kountze's 3rd Addition to City of Omaha, 910 F2d 488, 490-91 (8th Cir 1990); United States $v$ Bissell, 866 F2d 1343, 1348 n 3 (11th Cir 1989); United States v Markowski, 772 F2d 358, 362 (7th Cir 1985); Milicia, 769 F Supp at 886-87.

${ }^{2}$ United States $v$ Simmons, 154 F3d 765, 770-71 (8th Cir 1998); McHan, 101 F3d at 1041-43; United States v Hurley, 63 F3d 1, 21 (1st Cir 1995), cert denied, 517 US 1105 (1996); United States $v$ Saccoccia, 823 F Supp 994, 1003 (D RI 1993), affd, 58 F3d 754, 785 (1st Cir 1995), cert denied, 517 US 1105 (1996).

McHan, like Milicia, is a CCE case. The holding, however, probably extends to the forfeiture of proceeds under RICO. See note 25.

${ }^{27}$ United States $v$ DeFries, 129 F3d 1293, 1314-15 (DC Cir 1997) (standing for the narrow proposition that taxes, as overhead or fixed costs, are not deductible from the amount forfeitable to the government).

${ }^{23}$ In Masters, the court noted that Lizza, the first case to consider the definition of proceeds after the 1984 amendments, "came out the other way" and allowed the recovery of gross profits. Masters, 924 F2d at 1370 . Several cases acknowledge the disagreement between Lizza and Masters. See, for example, DeFries, 129 F3d at 1314 (stating that defendants cited Masters, and noting that McHan, Saccoccia, Hurley, and Lizza explicitly disagreed with Masters). Finally, Simmons described the battle lines as of 1998: the Seventh Circuit (Masters) favors a net profits definition of proceeds; the Second Circuit (Lizza) favors a gross profits view; and the First (Saccoccia and Hurley), Fourth (McHan), and D.C. Circuits (DeFries) define proceeds as gross revenues. Simmons, 154 F3d at 770. Simmons aligned the Eighth Circuit with the gross revenues group. Id. Note two things. First, Simmons does not add Milicia to the list of gross profits courts because Milicia was a district court, not an appellate court, case. Simmons surveys only appellate court cases. Second, although Simmons attributes the gross revenues view to the D.C. Circuit, DeFries is actually also consistent with a gross profits view since marginal costs were not an issue in that case. DeFries, $129 \mathrm{F3d}$ at 1313-14. 


\section{INTERPRETING THE RICO STATUTE}

\section{A. Statutory Text}

Section 1963(a)(3) subjects the "proceeds" of a RICO criminal enterprise to forfeiture. ${ }^{29}$ Determining the meaning of "proceeds" requires first looking at the statutory text. ${ }^{30}$ RICO itself nowhere defines the term "proceeds." The plain meaning of "proceeds" is ambiguous, but the statutory text may be read to support a gross revenues interpretation.

The dictionary definition of proceeds supports several interpretations. Merriam-Webster's first definition of proceeds is "the total amount brought in,"31 suggesting gross or total revenues. The second definition is "the net amount received . . . after deduc-

20 18 USC $\S 1963$ (a) reads:

Whoever violates any provision of section 1962 of this chapter shall be fined under this title or imprisoned not more than 20 years (or for life if the violation is based on a racketeering activity for which the maximum penalty includes life imprisonment), or both, and shall forfeit to the United States, irrespective of any provision of State law-

(1) any interest the person has acquired or maintained in violation of section 1962;

(2) any-

(A) interest in;

(B) security of;

(C) claim against; or

(D) property or contractual right of any kind affording a source of influence over;

any enterprise which the person has established, operated, controlled, conducted, or participated in the conduct of, in violation of section 1962; and

(3) any property constituting, or derived from, any proceeds which the person obtained, directly or indirectly, from racketeering activity or unlawful debt collection in violation of section 1962.

The court, in imposing sentence on such person shall order, in addition to any other sentence imposed pursuant to this section, that the person forfeit to the United States all property described in this subsection. In lieu of a fine otherwise authorized by this section, a defendant who derives profits or other proceeds from an offense may be fined not more than twice the gross profits or other proceeds.

${ }^{30}$ "In determining the scope of a statute, we look first to its language. If the statutory language is unambiguous, in the absence of 'a clearly expressed legislative intent to the contrary, that language must ordinarily be regarded as conclusive." United States $v$ Turkette, 452 US 576, 580 (1981), quoting Consumer Product Safety Commission v GTE Sylvania, Inc, 447 US 102, 108 (1980). See also Connecticut National Bank v Germain, 503 US 249, 253-54 (1992) ("חn interpreting a statute a court should always turn first to one, cardinal canon before all others. We have stated time and again that courts must presume that a legislature says in a statute what it means and means in a statute what it says there.").

${ }^{31}$ WWWebster Dictionary, available online at <http://www.m-w.com> (visited Aug 6, 1999). 
tion of any discount or charges," suggesting gross or net profits. ${ }^{32}$ Neither is obviously more appropriate than the other in the forfeiture context. Legal definitions suggest proceeds are gross revenues, but the legal context of these definitions differs from the forfeiture context. ${ }^{33}$ Black's Law Dictionary defines proceeds as "[t]hat which results, proceeds, or accrues, from some possession or transaction,"34 suggesting gross revenues as the proper definition. ${ }^{35}$ However, Black's draws its definition from a single case, State Highway Commission v Spainhower, ${ }^{36}$ which concerns state constitutional law, not criminal forfeiture. The former Section 9. 306 of the Uniform Commercial Code defined "proceeds" as "anything received from the disposition of a piece of collateral without a deduction for the price of the collateral."37 This definition again suggests a gross revenues interpretation. However, the context is secured creditor law, which may not be the appropriate baseline from which to determine proceeds in a criminal statute. Finally, investor dictionaries define "proceeds" in a context that is probably closer to RICO's-general business operations-but also prove unhelpful, as some define proceeds as gross revenues, others as revenues net of costs. ${ }^{38}$

Congressional use of "proceeds" in the Senate Report explaining the purpose of the 1984 amendments may avoid contex-

${ }^{32}$ Id. See also Merriam-Weỏster's Collegiate Dictionary 937 (Merriam-Webster 9th ed 1986) (providing the same two definitions); The Random House Dictionary of the English Language 1542 (Random House 2d ed unabridged 1987) ("a. something that results or accrues. b. the total amount derived from a sale or other transaction .... c. the profits or returns from a sale, investment, etc.").

*3 Plain meaning is not simply the dictionary definition, but also the contextual definition. Chisom v Roemer, 501 US 380, 404 (1991) (Scalia dissenting).

${ }^{3}$ Black's Law Dictionary 1204 (West 6th ed 1990).

${ }^{35}$ This is more like Merriam-Webster's first definition. Unlike the second definition, there is no mention of a deduction for costs.

${ }^{36} 504$ SW2d 121, 125 (Mo 1973).

${ }^{37}$ United States $v$ Elliott, 727 F Supp 1126, 1128 (N D Ill 1989), citing UCC $\$$ 9-306 (ALI 1989). The current Section 9-306 definition of proceeds seems as broad as the former definition, but does not explicitly indicate that costs must not be deducted: "Proceeds' includes whatever is received upon the sale, exchange, collection or other disposition of collateral or proceeds." UCC § 9-306 (ALI 1997).

${ }^{33}$ Moneywords 1999 Edition differentiates proceeds, which are gross revenues, from net proceeds, which are gross revenues less costs. Available online at $<$ http://www.moneywords.com> (visited Aug 6, 1999) (defining proceeds as “[m]oney or property which is received upon the sale, exchange, collection or other disposition of collateral"; defining net proceeds as the "[a]mount received after deduction of all costs incurred from the sale of real estate or securities"). However, InvestorWords-Investing Glossary does not differentiate proceeds and net proceeds on the basis of deducting costs. Available online at <http://www.investorwords.com> (visited Aug 6, 1999) (defining proceeds as "[m]oney received through a sale or loan, after any commissions and fees are deducted," and net proceeds as "[t]he amount of money received from a loan or a sale of property or securities, after subtracting transaction costs"). 
tual problems if one assumes Congress attempts to be consistent in its usage of "proceeds" in different parts of a report or a single bill. This usage suggests an interpretation greater than net profits. When discussing the "proceeds" from the government's sale of forfeited assets, Congress treats the government's expenses in arranging the sale as something to be deducted from proceeds, rather than something used to derive proceeds. ${ }^{39}$ The problem with relying on this usage here is that it is unclear whether the expenses Congress refers to are fixed costs or marginal costs. If only fixed costs are at issue,$^{40}$ then Congress's usage is consistent with both a gross profits and gross revenues approach.

Because the plain meaning of "proceeds" does not resolve the ambiguity of the term, defining the term requires analysis of the text surrounding Section 1963(a). ${ }^{41}$ The surrounding text, however, also does not resolve the ambiguity. Under one reading of the statutory language, because Section 1963(a)(3) authorizes forfeiture of proceeds received by the individual "person" rather than by the enterprise as a whole, only the defendant's wages plus her share of the enterprise's profits may be forfeited. ${ }^{42}$ Under this reading, the enterprise, not the defendant, "receives" profits that go to other participants and "pays" the costs owed to other

* $\mathrm{S}$ Rep No 98-225 at 194 (cited in note 18) ("The proceeds of the sale must be used to offset the government's expenses."). This is consistent with the Department of Justice's (DOJ") usage of "proceeds" around the time of the 1984 amendments. The DOJ used proceeds to describe gross revenues from the sale of forfeited assets and distinguished its costs in liquidating the assets as expenses subtracted from the proceeds of the sale. 50 Fed Reg 24054, 24054-55 (1985), reprinted in Forfeiture Issues, Hearing on HR 1193 before the Subcommittee on Crime of the House Committee of the Judiciary, 99th Cong, 1st Sess 111-12 (1986).

${ }^{*}$ The expense involved in selling forfeited assets does not vary much with the value of the object sold. The cost of selling a Ferrari or a Honda is the same, particularly if both are sold at an auction. To the extent that the cost of selling assets varies with the quantity of objects sold, if the objects are sold at an auction, the marginal costs are probably small compared to the fixed costs of arranging the auction in the first place. Once an auction is organized for the sale of a Ferrari, it is trivial to add a second Ferrari to the auction menu. Moreover, the cost of transferring title does not vary substantially across assets other than real estate. This all suggests that asset sales involve, and are probably thought of by Congress as involving, mainly fixed costs, not marginal costs.

"See Holloway v United States, 119 S Ct 966, 969 (1999) ("In interpreting the statute at issue, '[w]e consider not only the bare meaning' of the critical word or phrase 'but also its placement and purpose in the statutory scheme."), quoting Bailey $v$ United States, 516 US 137, 145 (1995).

${ }^{12}$ Section 1963(a)(3) only authorizes forfeiture of proceeds "which the [defendant] obtained." See United States v Masters, 924 F2d 1362, 1370 (7th Cir 1991). RICO's text refers to forfeiture of "any proceeds which the person obtained, directly or indirectly, from racketeering activity." 18 USC § 1963(a)(3) (emphasis added). Note that 18 USC $\$ 1961$ defines person to include any "entity capable of holding a legal or beneficial interest in property," suggesting "person" may include corporations. However, such a broad defini-. tion does not make sense in the context of 18 USC $\S 1963$. 
suppliers. But this interpretation ignores the fact that Section 1963(a)(3) applies to proceeds the defendant obtained both "directly [and] indirectly." Moreover, criminal conspiracy law typically permits defendants to be punished (usually through sentencing) for the acts of co-conspirators. ${ }^{43}$ Because RICO forfeiture punishes conspiracy, a benefit to the enterprise may properly be seen as an "indirect" benefit to the individual defendant." This indirect benefit might include profits received and costs paid by the enterprise. Neither reading seems obviously more correct than the other.

In the end, definitions in ordinary, legal, and investor dictionaries fail to provide an unambiguous "plain meaning" for "proceeds." Statutory context similarly provides no clear guidance. Arguably, congressional usage may solve the contextual problems with legal definition, but only partially remedies the ambiguity; it rules out a net profits approach, but is not clear which costs are deducted. Moreover, even if a textual analysis of the meaning of "proceeds" could tell us which costs, if any, defendants must forfeit, it tells us little about who ought to shoulder the burden of proof.

\section{B. Legislative History}

The legislative history of RICO supports a reading of proceeds that is greater than net profits, but not necessarily total revenues. ${ }^{45}$ The primary purpose of RICO is to slow the infiltration of organized crime into legitimate business organizations. ${ }^{46}$ The purpose of the forfeiture provisions in Section 1963(a) is to disgorge a criminal's ill-gotten gains and thereby remove the profit motive to infiltrate legitimate businesses. ${ }^{47}$ To further these goals, Congress amended RICO in the Comprehensive Crime Control Act of 1984 ("CCCA") to provide for the forfeiture of not just "interests" in a RICO enterprise, but also proceeds derived from prohibited racketeering activity. ${ }^{48}$ The legislative history of

${ }^{2}$ See USSG $\S 1 B 1.3(a)$.

4This argument is offered in United States v Saccoccia, 823 F Supp 994, 1004 (D RI 1993) (analogizing RICO forfeiture to sentencing for criminal conspiracy), affd, 58 F3d 754 (1st Cir 1995).

${ }^{4}$ If there is ambiguity in the text, courts may turn to the legislative history for guidance. See, for example, H.J., Inc $v$ Northwestern Bell Telephone Co, 492 US 229, 238-39 (1989) (using legislative history to interpret Section 1961(5) of RICO). See also John Paul Stevens, The Shakespeare Canon of Statutory Construction, 140 U Pa L Rev 1371, 1381 (1992).

${ }^{4}$ Russello v United States, 464 US 16, 27-28 (1983); Turkette, 452 US at 591.

${ }^{47}$ Russello, 464 US at 28.

${ }^{45} 18$ USC § 1963(a)(3). See text accompanying notes 15-19. 
the 1984 amendments strongly suggests that Congress saw proceeds as different from profits; ${ }^{49}$ Congress used "proceeds" instead of "profits" to relieve prosecutors of the burden of proving net profits and to make defendants forfeit at least some of their costs.

In the Senate Report on the CCCA, Congress indicated its concern for prosecutorial resources: "[T] he term 'proceeds' has been used in lieu of the term 'profits' in order to alleviate the unreasonable burden on the government of proving net profits. It should not be necessary for the prosecutor to prove what the defendant's overhead expenses were."50 If this concern was rooted simply in the typical accounting difficulties associated with determining profits, Congress probably intended for the government initially to seek forfeiture of at least net profits plus overhead (or fixed costs), which would be gross profits.

It is unlikely that Congress wanted courts, in the end, to authorize forfeiture of total revenues when a better proxy for net profits could be found with little effort. Otherwise, Congress would have simply required forfeiture of all revenues and not voiced any concern about the government's burden of proving profits.

The conclusion that Congress intended "proceeds" to mean gross profits is undercut somewhat by evidence that Congress was also concerned with accounting difficulties arising from bookkeeping trickery by defendants. When Congress added Section 1963(a)(3) to RICO, it also amended Section 1963(c) to close a loophole that had allowed defendants to "avoid criminal forfeiture by transferring [their] property to another person prior to convic-

40 See S Rep No 98-225 at 199 (cited in note 18). The importance of the distinction between "profits" and "proceeds" is evident in the statements of witnesses who appeared before Senate and House subcommittees considering the proposed amendments. See Comprehensive Crime Control Act of 1983, Hearings on S 829 before the Subcommittee on Criminal Law of the Senate Committee on the Judiciary, 98th Cong, 1st Sess 806 (1984) (prepared statement of William Greenhalgh, Section of Criminal Justice, American Bar Association) ('The word 'proceeds' suggests that the court should make no inquiry into the real profit from a criminal transaction. The defendant should not get to deduct his costs in determining what amount is appropriate to forfeit."); Forfeiture in Drug Cases, Hearings on HR 2646, HR 2910, HR 4110, and HR 5371 before the Subcommittee on Crime of the House Committee on the Judiciary, 97th Cong, 1st and 2d Sess 37, 39 (1983) (statement of William J. Anderson, Director, General Government Division, United States General Accounting Office) ("The CCE . . . speaks in terms of forfeiture of . . . 'profits'-a term commonly defined as the proceeds of a transaction less its cost. Under this definition, the costs of narcotics to a dealer are not profits, and a significant legal question exists as to whether proceeds allocable to costs are forfeitable under CCE."). The bills before Congress amended both CCE and RICO to include proceeds, not just profits and interests, respectively.

${ }^{5} \mathrm{~S}$ Rep No 98-225 at 199 (cited in note 18), citing United States $v$ Jeffers, 532 F2d 1101,1117 (7th Cir 1976), affd in part, vacated in part, 432 US 137 (1977). 
tion," even by "transfers that were not 'arms' length' transactions." "51 Surely such efforts to curb accounting tricks are not confined to the period after determining the amount subject to forfeiture. The possibility of manipulation before this amount is fixed suggests not only that the government should seek forfeiture of more than net profits, but also that courts should not allow defendants to shrink the forfeiture order by proving any costs. Otherwise, convicts will have another opportunity to evade punishment. ${ }^{52}$

Testimony from hearings on precursor bills to Title III of the CCCA offers a second possible reason why Congress sought forfeiture of proceeds rather than profits: to make forfeiture a heavier penalty. Consider the statement of New York Congressman Leo C. Zeferetti:

My bill, H.R. 4110, would make clear that forfeiture under the RICO Act Statute reaches all profits and proceeds of illegal activity covered by the RICO statute regardless of the form in which they are held, and whether such assets are held directly or indirectly by the violator. . . . [T] The amendment I propose to the CCE statute would make explicit that all "proceeds" of narcotics trafficking would be subject to forfeiture. . . . The difficulty with the [current] statute ... is that the concept of "profits" may not include the costs of operating a narcotics enterprise and hence only the net profits instead of gross profits from trafficking may be forfeitable. My bill would make clear that all proceeds of narcotics trafficking would be subject to forfeiture. The salutary effects of this change are two-fold. First, it is easier to prove the proceeds of an illegal activity as opposed to net profits. Second, a convicted trafficker would be denied recovery of his costs of conducting an illegal enterprise. Forfeiture will obviously be more effective when it encompasses all proceeds rather than merely profits. ${ }^{53}$

Zeferetti's statement shows that at least one member of Congress considered the change from "profits" to "proceeds" to entail a nec-

\footnotetext{
${ }^{81} \mathrm{~S}$ Rep No 98-225 at 200-01 (cited in note 18). Section 1963(c) now only allows defendants to avoid forfeiture of property acquired by an "innocent bona fide purchaser." Congress was acting on evidence that defendants actively used whatever transactions they could to hide assets from forfeiture.

${ }^{82}$ With enough leeway, defendants might be able to exaggerate costs so much that they will be able to evade forfeiture of even their actual profits. See note 79 and accompanying text.

${ }_{53}$ Forfeiture in Drug Cases, Hearings on HR 2646, HR 2910, HR 4110, and HR 5371 at 26 (cited in note 49) (statement of Rep Zeferetti).
} 
essary increase in the amount forfeited and believed that one of the benefits of this increase would be a RICO statute with a stronger deterrent effect. ${ }^{54}$

While an increase in the level of deterrence is one positive aspect of an increase in the amount forfeited, this increase may come at the expense of innocent third parties. If costs are forfeitable, employees, co-owners, and outside suppliers who were unaware of the enterprise's racketeering activity may go unpaid if complete forfeiture leaves the'defendant insolvent. Elsewhere in the legislative history of the 1984 amendments, Congress partially addressed this concern by clarifying that Section 1963(a)(3) does not reach legitimately earned profits, but only those produced "through a pattern of racketeering activity." nesses and members of Congress at hearings before the enactment of RICO in 1970 and the 1984 amendments expressed a similar concern for innocent outside suppliers. ${ }^{56}$ Congress ultimately failed to address this concern in either the 1970 Act or the 1984 amendments. ${ }^{57}$ Courts may interpret congressional inaction as an intent either to provide no protection for innocent suppliers or to allow courts to protect their interests. Neither interpretation

st Zeferetti was not alone in pointing out that proceeds are not only easier to prove, but also give forfeiture more bite. Consider the statement of David B. Smith and Edward C. Weiner from the Criminal Division of the Department of Justice: "The third advantage derives from the difference between 'profits' and 'proceeds.' It is easier to prove proceeds than net profits and the total forfeiture obviously will be greater where it encompasses all proceeds rather than merely profits." Criminal Forfeitures under the RICO and Continuing Criminal Enterprise Statutes 4-5 (Nov 1980), reprinted in Forfeiture in Drug Cases, Hearings on HR 2646, HR 2910, HR 4110, and HR 5371 at 270-71 (cited in note 49). Congress certainly paid careful attention to Smith and Weiner's statement. In the Senate Report on the CCCA, Congress cites the same case, United States $v$ Jeffers, that Smith and Weiner do to justify proceeds forfeiture. Compare S Rep No 98-225 at $199 \mathrm{n} 24$ (cited in note 18), with Criminal Forfeitures at $5 \mathrm{n} \mathrm{3,} \mathrm{reprinted} \mathrm{in} \mathrm{Forfeiture} \mathrm{in} \mathrm{Drug} \mathrm{Cases,} \mathrm{Hear-}$ ings on HR 2646, HR 2910, HR 4110, and HR 5371 at 271 ("In United States v. Jeffers ... the court took notice of 'the extreme difficulty in this conspiratorial, criminal area of finding hard evidence of net profits.' However, it will probably suffice to prove that a drug dealer bought a quantity of narcotics for, let us say, a million dollars and sold them for approximately three millions dollars, based on the known wholesale or street value of the drug. It should not be necessary for the prosecutor to prove what the defendant's overhead expenses were.").

${ }^{56} \mathrm{~S}$ Rep No 98-225 at 199 (cited in note 18).

${ }^{36}$ See Spaulding, $80 \mathrm{~J}$ Crim L \& Criminol at 226-32 (cited in note 19) (noting concern expressed by several witnesses and congressmen in 1981 regarding the lack of protection for innocent third parties).

William Greenhalgh of the ABA's Section of Criminal Justice voiced concern for suppliers in hearings before the 1984 amendments. Comprehensive Crime Control Act of 1983, Hearings on S 829 before the Subcommittee on Criminal Law of the Senate Committee on the Judiciary, 98th Cong, 1st Sess at 806 (cited in note 49) (suggesting that forfeiture be limited to profits in "those crimes in which the defendant renders a socially acceptable service, at a cost to himself, but there is criminality involved").

s7 Spaulding, $80 \mathrm{~J}$ Crim L \& Criminol at 237 (cited in note 19). 
would allow defendants to deduct costs owed to noninnocent suppliers. ${ }^{58}$ The statute does protect innocent outside purchasers in Section 1963(c), which entitles bona fide purchasers to a posttrial hearing under Section 1963(l) in which they may seek recovery of their purchases. ${ }^{59}$

The legislative history behind RICO shows that the purpose of RICO is to remove organized crime from legitimate business organizations by making commingling unprofitable. The legislative history suggests that the purpose of changing "interests" to "proceeds" in 1984 was both to alleviate the burden on prosecutors of proving overhead and hence "net profits" and to increase the penalty of forfeiture. Congress made clear that it wanted the government to seek forfeiture of more than profits and that neither defendants nor courts should deduct all costs from forfeiture orders. The risk of bookkeeping trickery if defendants are allowed to deduct any costs suggests perhaps gross revenues should be forfeited. However, Congress may also have been concerned for innocent third parties and could have specified "gross revenues" instead of "proceeds" if such was the forfeiture it intended. This suggests Congress wanted final forfeiture of something less than total revenues. Thus courts are left with two substantive constraints: prosecutors may seek and defendants must suffer forfeiture of more than net profits, but courts may order the forfeiture of something less than total revenues when a better proxy for net profits can be found. In addition, the legislative history imposes the procedural constraint that prosecutors should not have to prove costs-particularly overhead-when net profits are not obvious. The rest is subject to judicial discretion.

\section{The Rule of Lenity and RICO's Liberal Construction Clause}

The rule of lenity provides that where a criminal statute is ambiguous, it should be "strictly construed in favor of the defendant." "Proceeds" is not defined in the RICO statute and is not

\footnotetext{
ss This begs the question of what is innocent. See text accompanying note 88.

${ }^{\text {s9 }} 18$ USC $\$ 1963$ (c), (1). The 1984 amendments, while acknowledging the importance of protecting such purchasers, are actually more concerned with insuring that defendants, to avoid forfeiture, do not transfer such property to third parties. The CCCA amends Section 1963(c) to codify the "taint theory" under which "forfeiture relates back to the time of the acts which [gave] rise to the forfeiture." S Rep No 98-225 at 200 (cited in note 18). The codification requires that any transfer be at arms' length to innocent bona fide purchasers. Section 1963(c) did not previously impose this last requirement. Id at 201.

${ }^{\infty}$ David Kurzweil, Criminal and Civil RICO: Traditional Canons of Statutory Interpretation and the Liberal Construction Clause, 30 Colum J L \& Soc Probs 41, 50 (1996) (reviewing the justifications for the rule of lenity). See also United States $v$ Bass, 404 US 336,347 (1971) (" $[\mathrm{A}] \mathrm{mbiguity}$ concerning the ambit of criminal statutes should be resolved
} 
susceptible to a single plain meaning; the resulting ambiguity seems to call for application of the rule. Construing "proceeds" in the manner most favorable to RICO defendants obviously entails interpreting it to set the lowest possible upper bound on RICO forfeiture. At first blush, this may seem to be net profits. ${ }^{61}$

The rule of lenity, however, cannot produce a result contrary to congressional intent. ${ }^{62}$ Applied to Section 1963(a)(3), the rule may do just that. First, Congress deliberately used "proceeds" instead of "profits" to alleviate the government's burden of having to prove net profits. The legislative history behind the 1984 amendments suggests that proceeds are greater than profits by at least the amount of overhead. ${ }^{63}$ Second, Congress included a clause in RICO that tells courts to "liberally constru[e]" the statute's provisions to "effectuate its remedial purposes." 64 This clause seems specifically to prohibit rigid application of the rule of lenity ${ }^{65}$ Moreover, the rationale behind the rule of lenity may not be as powerful in the context of criminal forfeiture as with imprisonment because the former is a lesser threat to personal liberty. ${ }^{66}$

in favor of lenity."), quoting Rewis $v$ United States, 401 US 808, 812 (1971); Russello, 464 US at 29 (refusing to apply the rule of lenity because the Court found the term "interests" to be clear).

"1 This would narrowly construe the forfeiture penalty to impose no burdens on a defendant arising from ambiguity in the meaning of proceeds.

62 Turkette, 452 US at 587-88 $\mathrm{n} 10$ ("The canon in favor of strict construction of [criminal statutes] is not an inexorable command to override common sense and evident statutory purpose."), quoting United States v Moore, 423 US 122, 145 (1975). Turkette rejected application of the rule of lenity because it felt the meaning of the term "enterprise" was clear from RICO's legislative history.

See text accompanying notes 49-50. Although the rule of lenity cannot circumvent congressional intent, perhaps it may still apply to those choices not inconsistent with that intent. Such an understanding of the rule of lenity rules out a net profits approach as incompatible with legislative purpose and a gross revenues approach as contrary to the rule of lenity.

${ }^{*}$ Organized Crime Control Act of 1970, Pub L No 91-452, 84 Stat 922, 947, codified at 18 USC $\$$ 904(a) (1994).

${ }^{\infty}$ As a result, courts have not applied the rule in RICO cases. See Kurzweil, 30 Colum $\mathrm{J} L \&$ Soc Probs at 42 n 6 (cited in note 60). Professor Dan Kahan suggests that courts generally do not apply the rule of lenity when Congress delegates criminal lawmaking powers to them. Dan M. Kahan, Lenity and Federal Common Law Crimes, $1994 \mathrm{~S}$ Ct Rev 345, 346-47. Statutes that delegate such power employ broad statutory language. In such cases, a "narrow [ ] 'rational reading" of a criminal statute is impossible. Id at 347. Instead Congress intended courts to craft "judge-made law ... to fill the interstices of opentextured statutory provisions." Id. Kahan considers RICO a model delegation statute, using broad language such as "pattern of racketeering activity" in the context of an "enterprise." Id at 378-80. Courts have responded not by trying to strictly construe RICO under the rule of lenity, but by "fashion[ing] a body of RICO law every bit as rich as the judgemade law of criminal fraud." Id at 381 . Kahan argues that this is both what Congress intended and what is usually efficient. Id at $381,413$.

${ }^{6}$ Professor Kahan suggests that the rule of lenity "embodies our legal system's in- 
The liberal construction clause itself suggests a reading of proceeds as something greater than net profits. ${ }^{67}$ The clause does not necessarily require the heaviest conceivable penalty, however, bounded only by constitutional constraints. Instead, it urges liberal construction whenever a lesser penalty would not adequately carry out the purposes of the statute. An appropriately restrained understanding of the liberal construction clause, therefore, probably rules out net profits-because they are simply too low to "effectuate [RICO's] remedial purposes"68_but does not preclude something less than gross revenues as long as the lesser amount is sufficient to fulfill RICO's goals. The question becomes at what level-total revenues, total revenues minus marginal costs, or something else entirely-the definition of "proceeds" adequately "effectuates" RICO's purposes within the meaning of the clause.

\section{A PRoposed Definttion FoR "ProceEdS"}

Textual analysis of Section 1963(a)(3) rules out, if anything, a net profits interpretation of proceeds, but tells courts little about what the government may initially petition to seize and what defendants must finally forfeit. The legislative history indicates that the government may initially seek and defendants must finally surrender more than net profits. The legislative history also suggests that defendants cannot be made to forfeit total revenues because, among other reasons, Congress could easily have specified a gross revenues forfeiture if it so intended, and defendants rather than prosecutors should have to bear the burden of providing any costs to be deducted from total revenues when calculating the amount to forfeit. Beyond these constraints, courts only have the rule of lenity and RICO's liberal construction clause to guide them. Not surprisingly, courts' interpretations of "proceeds" are distributed across the entire spectrum of possible meanings of that term.

This Comment advocates an alternative definition of proceeds that lies between total revenues and gross profits. ${ }^{69}$ This definition would allow the government initially to seek forfeiture

stinctive distaste against men languishing in prison unless the lawmaker has clearly said they should." Kahan, $1994 \mathrm{~S} \mathrm{Ct}$ Rev at 345-46 (cited in note 65), quoting Bass, 404 US at 348.

${ }^{67}$ One court has made this argument to justify a broad reading of "proceeds." United States v Lizza Industries, Inc, 775 F2d 492 (2d Cir 1985) (holding that proceeds are gross profits or total revenues minus only marginal costs).

* 18 USC $\$ 904(a)$.

ต Gross profits, again, is total revenues minus all marginal costs. 
of total revenues from illegal operations minus marginal costs from illegal operations that are themselves "legitimate"70 expenditures. If the government were to seek a forfeiture amount that included any legitimate marginal costs, either the defendant could request their deduction or the court could deduct them on its own initiative. This rule balances the legislative goals behind RICO with Congress's concerns about the effects of forfeiture on innocent third parties, ${ }^{71}$ at the same time offering advantages neither Congress nor courts contemplated.

To understand the proposed definition of "proceeds," consider the model of a RICO enterprise in Figure 1. This model RICO enterprise has two parts: one that conducts legal operations and one that conducts illegal operations. ${ }^{22}$ Total revenues from illegal op-

20 "Legitimate" transactions are those that are themselves legal. "Illegitimate" transactions are those that, standing alone, violate some law or involve the exchange of a commodity illegally acquired. Examples of illegitimate transactions include purchases of contraband, bribes, and drug sales. An example of a legitimate purchase that becomes illegitimate only in the context of a RICO violation is the purchase by a pharmacy of prescription drugs that are subsequently dispensed under illegal prescriptions. See United States v Milicia, 769 F Supp 877 (E D Pa 1991).

"Two other commentators have considered the question of the proper (and optimal) definition of proceeds. Karla R. Spaulding argues for a total revenues interpretation. She argues that the outcome in United States v Lizza Industries, Inc, $775 \mathrm{~F} 2 \mathrm{~d} 492$ (2d Cir 1985) (interpreting "proceeds" to be gross profits), is inconsistent with the legislative history of RICO and its 1984 amendments, as well as case law in other contexts that holds that a defendant forfeits his or her rights to illegal expenditures such as bribes. Spaulding, $80 \mathrm{~J}$ Crim L \& Criminol at 261-62 \& $n 388$ (cited in note 19). Spaulding, however, did not consider the definition advanced in this Comment as a possible interpretation of "proceeds." This definition addresses her concerns with respect to both the legislative history of RICO and the case law from other areas. Writing just after Lizza, Spaulding does not address the arguments in United States v Masters, 924 F2d 1362 (7th Cir 1991), and Milicia, 769 F Supp 877, or many of the arguments raised in this Part.

A second commentary, Note, A Proposal to Reform Criminal Forfeiture under RICO and CCE, 97 Harv L Rev 1929, 1941 (1984), argues for a net profits interpretation because gross profits may require seizure of overhead costs used to provide "a socially useful service." The commentator argues that seizing gross profits leads to an absurd result: nonviolent white-collar crime, which is likely to provide more socially useful services, will be punished more than violent crime due to the fact that white-collar crime has more overhead expenses. Id at 1941-42. The definition proposed in this Comment partially addresses this problem by requiring only the forfeiture of marginal costs that are not related to the enterprise's illegal activities. Moreover, the Note evaluates an incomplete view of RICO punishments in two senses. First, RICO still punishes nonviolent organizations that are not infiltrated less than either (a) nonviolent organizations that are infiltrated or (b) violent organizations. It only punishes nonviolent organizations infiltrated by organized crime more than violent ones so infiltrated. The overall result is not just to punish violence, but to punish violence and merger. Second, the Note ignores the dynamic implications of larger punishments for nonviolent infiltrated organizations: if RICO deters infiltration, organized crime may be driven out of nonviolent organizations, freeing the latter from any forfeiture risks.

${ }^{72}$ But see United States v Turkette, 452 US 576, 591 (1981) (stating that "RICO is equally applicable to a criminal enterprise that has no legitimate dimension or has yet to acquire one"). 
erations (the area outlined by the dotted line) comprise illegal net profits, overhead, ${ }^{73}$ and legitimate and illegitimate marginal costs. ${ }^{74}$ Total revenues from legal operations include legal net profits, overhead, and legitimate marginal costs. Legal and illegal operations share common overhead costs.

Figure 1: The RICO Enterprise

\begin{tabular}{|c|c|c|}
\hline \multicolumn{3}{|c|}{ RICO Enterprise } \\
\hline \multicolumn{2}{|c|}{ Illegal Sales/Operations } & $\begin{array}{c}\text { Legal Sales/ } \\
\text { Operations }\end{array}$ \\
\hline $\begin{array}{l}\text { Illegitimate } \\
\text { Marginal } \\
\text { Costs }\end{array}$ & $\begin{array}{l}\text { Legitimate } \\
\text { Marginal } \\
\text { Costs }\end{array}$ & $\begin{array}{c}\text { Legitimate } \\
\text { Marginal } \\
\text { Costs } \\
\end{array}$ \\
\hline O & $\mathbf{E} \quad \mathbf{R} \quad \mathbf{H}$ & A $\quad$ D \\
\hline TIle & NetProfits & $\begin{array}{l}\text { Legal Net } \\
\text { Profits }\end{array}$ \\
\hline
\end{tabular}

Congress enacted RICO in order to discourage organized crime. This requires reducing the level of illegal operations-the area outlined by the dotted line in Figure 1. Congress expressed concern, however, that this be accomplished without undue harm to innocent third parties, such as those owed legitimate marginal costs. ${ }^{75}$ The scope of proceeds proposed here-total revenues from illegal operations minus legitimate marginal costs from illegal operations, ${ }^{76}$ the shaded area in Figure 1 -promotes both of these goals.

${ }^{73}$ Overhead, or fixed costs, are costs that do not vary with the quantity produced.

${ }^{74} \mathrm{~A}$ marginal cost is one that varies with the quantity produced. Whether a cost is fixed or marginal may depend on the time frame that you consider. For example, an automobile plant may be a fixed cost for a car company in any given year, but over a quarter century, that plant is a marginal cost because the total output of a company can change dramatically in twenty-five years. The time frame reference against which one should evaluate whether a cost is fixed or marginal is open to debate. A number of factors should be considered, such as the nature of the product, the other costs, and the evolution of the industry. Often a good starting point is a fiscal year or an earnings quarter.

${ }^{75}$ See text accompanying notes 55-58.

${ }^{76}$ Note that the proposed definition is a subtracting exercise: start with total revenues and subtract legitimate marginal costs. Treating this as an adding exercise would be very difficult because it is difficult to allocate the overhead between legal and illegal operations. See text accompanying notes 78-80. 
To see how, first consider why the proposed definition sets an appropriate lower bound for the definition of proceeds. Defendants forfeiting "proceeds" should not be allowed to deduct overhead, let alone all costs. ${ }^{77}$ Lacking accounting expertise, prosecutors may overestimate costs or mistakenly allocate overhead from legitimate operations to illegitimate operations. ${ }^{78}$ Criminals can manipulate their books ${ }^{79}$ to encourage such mistakes. Congress did not want to impose these accounting burdens on prosecutors. ${ }^{80}$ These burdens increase the cost to law enforcement and lower the racketeer's costs of violating the law. In addition, accounting errors that overestimate costs risk underdeterrence. ${ }^{81}$ Courts may

"Some courts have argued that allowing deductions for all costs fails to punish criminals who engage in racketeering, but do not turn a profit. United States $v$ Simmons, 154 F3d 765, 771 (8th Cir 1998); United States v McHan, 101 F3d 1027, 1042 (4th Cir 1996), cert denied, 520 US 1281 (1997). This result may affect the expressive value of the punishment, but it does not exacerbate the underdeterrence problem. In fact, ex post calculation of profits here punishes criminals more than ex ante calculation of profits because it does not compensate criminals when they lose money. This extra punishment comes in handy when the probability of ultimately convicting the criminal is less than one. An ex post profits fine does create incentives for criminals to infiltrate less risky businesses, but it is not obvious that this is bad, unless by legitimate businesses Congress meant less risky ones. In fact, one might suppose that less risky businesses are easier for law enforcement to monitor. In any case, requiring forfeiture of costs does not change this incentive, unless costs fall with risks, an assumption that is not compelling on its face.

${ }^{78}$ Lizza, 775 F2d at 498-99. See also United States $v$ DeFries, 129 F3d 1293, 1314 (DC Cir 1997).

${ }^{79}$ See Lizza, $775 \mathrm{~F} 2 \mathrm{~d}$ at 498-99. One can imagine criminals overcharging for services to one another in order to avoid forfeiture, just as multinational corporations engage in transfer pricing to evade tax laws. See id; McHan, 101 F3d at 1042.

Criminals would have an incentive to exaggerate legitimate marginal costs of illegal operations under the proposed definition. However, legitimate marginal costs are easier to allocate between legal and illegal operations precisely because they are marginal. They involve fewer scale economies. They do not overlap in usage.

${ }^{2}$ See S Rep No 98-225 at 199 (cited in note 18). All decisions after the 1984 amendments that take either a gross profits or total revenues approach make this argument. See, for example, Milicia, 769 F Supp at 887; DeFries, 129 F3d at 1315 (noting that Congress wanted to avoid burdening prosecutors with "technical tax calculations").

"Lizza, 775 F2d at 498-99; McHan, 101 F3d at 1042. See also A. Mitchell Polinsky and Steven Shavell, Should Liability be Based on the Harm to the Victim or the Gain to the Injurer?, $10 \mathrm{~J} \mathrm{~L} \mathrm{Econ} \mathrm{\&} \mathrm{Org} 427$ (1994) (arguing that where the gain to the injurer is uncertain, there is a risk of underdeterrence and perhaps harm to the victim should be used as the measure of damages).

Just as there is a risk of underdeterrence, there is a risk of overdeterrence. The two margins at which this might occur are (a) where firms decide to join two operations, one of which might be illegitimate, and (b) where, after merging, a firm decides at what level to engage in illegitimate operations. The harm of overdeterrence is probably less than that of underdeterrence at both margins. Consider, first, the decision to merge. Merger has one benefit-it raises the profits for the illegitimate activity. The cost of overdeterrence is the loss of that profit. If Congress does not consider profits from illegitimate activity as enhancing social welfare, then there is no cost to overdeterrence at this margin. Relatedly, one might be concerned that firms with separate but legal operations may avoid certain business tactics that are in fact legal and cost reducing because they are worried that the 
end up requiring forfeiture of an amount less than the criminals' actual ill-gotten gains, making criminal activities profitable even after punishment. The problem becomes worse if the probability of apprehension and conviction is less than one.

Courts should not allow deduction from forfeiture of all marginal costs. Deduction of all marginal costs (resulting in the forfeiture of only net or gross profits) will not affect the level of illegal activity in which criminals engage. Consider, for example, the facts of United States $v$ Milicia. ${ }^{82}$ Milicia was a pharmacist who filled illegally written prescriptions.$^{83}$ His total revenues were the amount customers paid for filled prescriptions. His fixed costs included his payroll and taxes, neither of which was, in the short term, a direct function of the amount of drugs dispensed. ${ }^{84}$ Suppose Milicia starts out with an initial wealth of $\$ 1,000$. Assume his marginal costs-the amount required to procure drugs-are $\$ 10$ per bottle, his fixed costs are $\$ 500$, and the price at which he can sell each bottle is $\$ 15$. If Milicia makes 1,000 sales, he makes a net profit of $\$ 4,500$ ( $\$ 15,000$ total revenues $-\$ 10,000$ marginal costs - $\$ 500$ fixed costs). If he makes 2,000 sales, he makes a net profit of $\$ 9,500$ ( $\$ 30,000$ total revenues $-\$ 20,000$ marginal costs - $\$ 500$ fixed costs). If the government seized only Milicia's net profits, Milicia is left with the same amount- $\$ 1,000$, his initial wealth-whether he sells 1,000 or 2,000 bottles. $^{85}$

criminal justice system might see them as illegal. But the overdeterrence risk here is a problem not with large penalties per se, but with unclear lines between legal and illegal acts. See Richard A. Posner, An Economic Theory of the Criminal Law, 85 Colum L Rev 1193,1221 (1985). Courts can address this problem by defining the elements of a RICO offense clearly. Moreover, RICO has built-in safeguards against overdeterrence. For example, isolated racketeering acts are insufficient for liability-multiple acts are required. 18 USC $\S 1961$ (5). Finally, every law risks overdeterrence. The important question is whether the harms Congress sought to avoid are worse than the social benefit from the behavior overdeterred. Given the zeal with which Congress approached RICO in 1970, it seems reasonable to suppose that Congress thought the harms from infiltration of legitimate businesses by organized crime outweighed the cost-cutting benefits from multiple, almostracketeering acts.

The cost of overdeterrence at the second margin is a suboptimal level of activity in illegitimate operations. Again, since Congress probably does not consider such activity to be in the social interest in the first place-that is, the optimal level of such activity is zerothere is no harm from overdeterrence.

It is also worth noting that the risk of overdeterrence is less than the risk of underdeterrence because there is no risk of manipulation by criminals to underestimate costs.

769 F Supp 877 (E D Pa 1991).

(Id at 879-80. Note that the prescriptions, not the drugs themselves, were illegal. The pharmacist did not receive any kickbacks or bribes to accommodate customers with illegal prescriptions. Referrals themselves were consideration for fulfilling unnecessary prescriptions.

st See note 102.

ss Even if Milicia were required to forfeit fixed costs but not any marginal costs, Milicia would end up with $\$ 500$ ( $\$ 1,000$ initial wealth $-\$ 500$ fixed costs) regardless of 
Although this suggests that some marginal costs should be seized to discourage illegal activity levels, the government need not seize all marginal costs. Courts should authorize seizure of only marginal costs that are themselves illegal transactions (these are "illegitimate" marginal costs in Figure 1). These costs are an indirect measure of the social harm from the RICO enterprise's operations. ${ }^{86}$ Charging enterprises this cost forces them to internalize the harm they are doing to society.

Because Congress was concerned about the effect of forfeiture on innocent third parties, courts should allow defendants to deduct from the forfeiture amount marginal costs that result from legal transactions. RICO currently protects innocent purchasers by providing post-seizure proceedings in which they can seek to recover their property, but it fails to protect similarly innocent suppliers. It seems logical to extend this congressional solicitude for the rights of innocent purchasers to the rights of innocent suppliers, which can easily be done by interpreting "proceeds" to exclude legitimate marginal costs. If judges allow deductions for marginal costs paid to suppliers of legal products, courts can protect these innocent suppliers without seriously compromising the deterrent effect of proceeds forfeiture. ${ }^{87}$ Individuals who transact in legal products are likely to be parties who would have qualified as innocent third party purchasers entitled to a return of the property seized by the government from RICO defendants under Section 1963(c). Congress was concerned about such people not because of their status as suppliers or purchasers, but because of their innocence. ${ }^{88}$

To summarize, charging for illegitimate marginal costs decreases the level of illegal activity and forces defendants to internalize the harm they have caused society. At the same time, al-

whether he sells 1,000 or 2,000 bottles. Milicia has no incentive to limit the number of illegal prescriptions he fills unless some of his marginal costs are seized because only marginal costs vary with his activity level.

${ }^{86}$ See United States v Hurley, 63 F3d 1, 21 (1st Cir 1995), cert denied, 517 US 1105 (1996); United States v Saccoccia, 823 F Supp 994, 1003 (D RI 1993), affd, 58 F3d 754 (1st Cir 1995), cert denied, 517 US 1105 (1996).

${ }^{87}$ To some extent, allowing deduction of legitimate marginal costs undercuts the incentives provided by overhead forfeiture to separate legitimate and illegitimate businesses. Since racketeers would be able to deduct marginal costs that were legitimate, they would have less disincentive to infiltrate legitimate businesses. Two things mitigate this concern. First, unless a legitimate business has no fixed costs, overhead forfeiture still provides a disincentive to infiltrate that business. Second, legitimate businesses with no fixed costs are not very common. These businesses have fewer incentives, under the guise of secrecy, to keep payroll limited or avoid large, noticeable purchases.

${ }^{88}$ See S Rep No 98-225 at 209 (cited in note 18). Moreover, deducting only legitimate marginal costs will increase the price of selling illegal products to other illegal organizations and, indirectly, the cost of selling illegal products at all. 
lowing deductions for marginal costs for legitimate transactions mitigates the harm of forfeiture to innocent third-party suppliers.

\section{THE PROPOSED DEFINITION EXPLAINS ACTUAL OUTCOMES IN MOST RICO CASES}

The scope of proceeds forfeiture advocated here is consistent with the outcomes of the leading cases from almost every circuit that has considered the proceeds issue, suggesting that courts share the same intuition about what the correct result should be. By announcing different formal definitions, however, the case law fails to provide clear guidance to lower courts. The courts' common intuition makes possible the adoption of the proposed definition of proceeds - total revenues less any marginal costs that are "legitimate"-without overruling the outcomes in previous cases.

The Second Circuit and a district court in the Third Circuit announced their gross profits forfeiture rules in United States $v$ Lizza Industries, Inc ${ }^{89}$ and United States $v$ Milicia ${ }^{90}$ respectively. The defendants in Lizza colluded on bids for government construction contracts. ${ }^{91}$ Their revenues were the amounts municipalities paid them for construction. The fixed costs of the scheme were payroll, large capital inputs such as cement mixers, and taxes. ${ }^{92}$ These costs did not vary in the short run with the amount of construction. The marginal costs were items such as cement, which varied with the quantity of construction. The defendant in Milicia was a pharmacist who filled illegal prescriptions written by co-conspirator doctors. ${ }^{93}$ Both courts held that the defendants could not deduct fixed costs from the total revenues to be forfeited, but permitted a deduction for marginal costs. ${ }^{94}$ While the cases state that the government may not seize marginal costs, the marginal costs in neither case were illegal expenditures. In Lizza

775 F2d 492, 498 (2d Cir 1985).

$₫ 769$ F Supp at 888 .

91 775 F2d at 494 .

92 Taxes other than sales taxes are in some sense fixed costs and in some sense marginal costs. First, to the extent that taxes are paid on payroll, which is a fixed cost, taxes are a fixed cost. Second, the taxes paid on profits are closer to marginal costs since profits increase with quantity sold. However, profits are not fully determined by looking at the price per quantity and the marginal cost. Fixed costs must also be deducted. Separating the fixed costs that should be charged to profits from illegal contracts versus profits from legal contracts implicates precisely the accounting difficulties of which Congress wanted to relieve prosecutors. Both reasons argue for treating taxes as fixed costs.

769 F Supp at $879-80$. See text accompanying notes $82-84$.

${ }^{24}$ Lizza, 775 F2d at 498; Milicia, 769 F Supp at 888. 
the marginal cost was cement and in Milicia it was prescription drugs. ${ }^{95}$

The First, Fourth, and Eighth Circuits have stated a total revenues rule. None of the rule-setting cases in these circuits involved legitimate marginal costs that could have been deducted. In United States $v$ Saccoccia ${ }^{96}$ and United States $v$ Hurley ${ }^{97}$ the First Circuit considered separate appeals from the same district court case ${ }^{98}$ involving defendants who laundered over $\$ 136$ million for Colombian drug lords. ${ }^{99}$ The final product in this case was clean money. The inputs were drug money and the transaction and labor costs of laundering money. The first input, drug money, was a marginal cost. ${ }^{100}$ The more clean money the defendants wanted to produce, the more drug money they needed. The transaction costs were also marginal costs, since they varied with the amount of money laundered. Both marginal costs were illegitimate expenditures. ${ }^{101}$ Labor costs are typically considered fixed costs. ${ }^{102}$ The district court held, and the First Circuit agreed, that

${ }^{\infty}$ In Milicia the prescriptions themselves were illegal, but the actual drugs were not.

${ }^{\circ} 58$ F3d 754, 782-85 (1st Cir 1995).

${ }^{97} 63$ F3d 1, 20-22 (1st Cir 1995).

United States v Saccoccia, 823 F Supp 994 (D RI 1993).

${ }^{\infty}$ Id at 998-99.

${ }^{100}$ The price of the first input is the implicit price or value of the unclean money. The dollar amount of the unlaundered money should be distinguished from the value or price of that money. The value of that money is less than the dollar amount of the money because the unclean money is worth its dollar amount times the probability that it will not be seized by the government as drug money. A good estimate of the value of the unclean money is the dollar amount of clean money transferred to the drug lords after the defendants eliminated the probability that the government would seize the money by disguising its connection to any drug transactions. Another way of estimating the same thing is the amount at which the drug lords could have sold their unclean money to any buyer. That buyer could, by paying any launderer the amount of the commissions paid to the defendants, receive the very same amount in actual clean money.

${ }^{101}$ The purchase or bailment of unclean money and the transaction costs in cleaning it are illegitimate marginal costs because they both involve the exchange of a product that is itself illegally acquired. See note 70 .

${ }^{102}$ This is not an obvious proposition. Deciding which inputs are fixed and which are marginal can be very difficult. Payroll obviously has a fixed component and a variable component within any given time frame. The same is true even with the transaction costs in this case. There are fixed costs to setting up fake accounts and variable costs to transferring money between them. Deciding whether a given cost is fixed or marginal is usually an intuitive judgment, often fraught with errors. To maximize the weighted sum of error costs and decision costs, judges should (and probably do) consider the following three obvious rules. First, the larger the share of total costs for a particular type of input that are fixed, the more likely that type of input should be considered a fixed cost. Second, the longer the time horizon over which an input varies in response to changes in quantity produced, the more likely that input should be considered fixed. Finally, the harder it is for judges to separate out the fixed and variable components of an input-or even to follow the previous two rules-the more likely it should be that judges consider the input's costs fixed. 
total revenues were forfeitable, ${ }^{103}$ with total revenues ${ }^{104}$ defined as the dollar amount of the clean money produced before it was transferred to the drug lords. ${ }^{105}$ In Saccoccia and Hurley, however, the forfeited marginal costs were all illegitimate expenditures.

The Fourth Circuit in United States $v \mathrm{McHan}^{106}$ considered the case of a defendant who distributed marijuana. ${ }^{107}$ The court held that the defendant had to forfeit his total revenues-the amount he received from sales of marijuana. ${ }^{108}$ The marginal costs were the costs of procuring marijuana. The record reported no fixed costs. ${ }^{109}$ Again, though the court announced its rule in broad terms, the sole cost forfeited was an illegitimate marginal one: the cost of marijuana.

The Eighth Circuit is the most recent circuit to consider the definition of proceeds. The defendants in United States $v$ Simmons $^{110}$ were government officials and a lobbyist, Simmons. The government officials, in return for kickbacks, referred industry groups to Simmons and helped get legislation passed for her clients. ${ }^{111}$ The total revenues of the enterprise were the receipts from the lobbying contracts Simmons had with industry groups. The government sought complete forfeiture, and Simmons sought to deduct the marginal costs of lobbying, excluding bribes. ${ }^{112}$ (The bribes paid to government officials were marginal costs for Simmons's lobbying firm, but not for the enterprise generally. Because the enterprise included the government officials Simmons bribed, those kickbacks were merely transfers within the enter-

\footnotetext{
${ }^{103}$ The district court stated its belief that RICO requires forfeiture of an amount somewhere between the entire amount laundered and the net profits received by each defendant. Saccoccia, 823 F Supp at 1002-03. The court went on to conclude, however, that the defendants could not deduct any of the costs at issue in that case-which comprised both fixed costs and illegitimate marginal costs-and ordered the defendants to jointly forfeit the entire $\$ 136$ million in revenue. Id at 1003, 1006-07.

${ }^{104} \mathrm{By}$ contrast, the net profit was the commissions the defendant launderers received minus their transaction and payroll costs.

${ }^{105}$ Saccoccia, $823 \mathrm{~F}$ Supp at 1006. This is also not an obvious claim. It is analogous to saying that the gross revenues of a dry cleaner include the clothes that it cleans and the price of the dry cleaning service. The complications here are that money laundering is a service and that the product created is itself money. To fit this fact pattern into traditional economic notions of revenues and costs, notice that this is a case where the consumer drug lords are also suppliers of the first input, the unclean money.

${ }^{106} 101$ F3d 1027 (4th Cir 1996), cert denied, 520 US 1281 (1997).

${ }^{107}$ Id at 1031.

${ }^{108}$ Id at 1042.

${ }^{100}$ Id at 1033.

${ }^{110} 154$ F3d 765 (8th Cir 1998).

"'Id at 766-67.

${ }^{112}$ Id at 770 .
} 
prise.) The court held that Simmons had to forfeit her total revenues and could not deduct her costs of lobbying. ${ }^{113}$ The lobbying expenses were illegitimate marginal costs because they were paid to the defendant herself for activity that violated the RICO statute.

The D.C. Circuit has not fixed a precise rule, but in United States $v$ DeFries ${ }^{114}$ it specifically rejected a net profits rule. The court did not address the larger question of the meaning of proceeds, only the narrow issue of whether taxes, usually considered to be a fixed cost, may be forfeited. ${ }^{115}$ The defendants in DeFries were union officers who engineered a merger with a second union and then claimed unauthorized severance payments, even though they kept their jobs. ${ }^{116}$ The total revenues of the enterprise were simply the severance payments. The overhead was the taxes they paid on those payments. In a per curiam decision, the court ruled that the officers could not deduct their taxes. ${ }^{117}$ No marginal costs were at issue.

The only case that cannot be reconciled with the definition of proceeds advanced in this Comment is the Seventh Circuit's decision in United States $v$ Masters. ${ }^{118}$ Masters was a lawyer who bribed Chicago cops to refer criminal defendants to him, to leave his bookmaking clients alone, and to kill his wife and cover up the murder. ${ }^{119}$ The lawyer's revenues were all the income he received from criminal clients who were referred by his coconspirator cops or who benefited from protection by bribes to these same cops. ${ }^{120}$ The court allowed the lawyer to deduct onethird of the fees and bribes he received as costs ${ }^{121}$ although they were clearly illegitimate marginal costs. Masters does not actu-

\footnotetext{
${ }^{113}$ Id at 770-71.

114 129 F3d 1293 (DC Cir 1997). The court reversed the conviction due to improper jury instructions, and as a result, reversed the forfeiture penalties. The court, however, went on to examine the forfeiture questions raised, because they were a matter of first impression in the D.C. Circuit.

${ }^{115}$ DeFries stands for the narrow proposition that taxes are not deductible from the amount forfeitable to the government, because they are part of overhead costs. Id at 131315. Other courts agree that taxes are overhead. See, for example, Lizza, 775 F2d at 498; Milicia, 769 F Supp at 889-90; United States v Elliott, 727 F Supp 1126, 1129 (N D IIl 1989).

${ }^{116} 129$ F3d at 1297.

"Id at 1313-15.

${ }^{118} 924$ F2d 1362 (7th Cir 1991).

${ }^{119}$ Id at 1365-66.

${ }^{120}$ The court did not mention any benefits Master received from the murder of his wife in its discussion of the amount to be forfeited by the defendants. Id at 1369.

${ }^{121}$ Id at $1369-70$.
} 
ally address the question of whether overhead is forfeitable because fixed costs were not an issue. ${ }^{122}$

The fact that the controlling cases ${ }^{123}$ in nearly every other circuit that has considered the scope of proceeds forfeiture can be reconciled with the definition of proceeds advocated in this Comment is a strong argument for adopting this definition. ${ }^{124}$ The change to existing law would only be incremental and not a complete reversal.

\section{LIMITATIONS ON FORFEITURE}

Although the proposed definition has some attractive properties, it faces a number of prudential limitations. First, many criminals face credit constraints that make forfeiture an incomplete solution. For example, in Saccoccia, the defendants were money launderers who had already transferred the money they cleaned to their drug lord clients. ${ }^{125}$ While the entire $\$ 136$ million laundered was forfeitable as "proceeds,"126 the defendants could not cover that fine with money in their possession. Ordinarily Section 1963(c) would entitle the government to seize property transferred to third parties who are not bona fide purchasers, but the government in Saccoccia could not realistically reach prop-

${ }^{122}$ The D.C. Circuit in DeFries makes this very point when it notes that Masters only considered the issue of bribes, which are like marginal costs, and not like taxes, which are more like overhead. DeFries, 129 F3d at 1314.

${ }^{123}$ Older cases within some of these circuits also apparently apply the modified gross proceeds definition. In Elliott, the defendant used confidential client information he received as a partner at a law firm to make lucrative stock trades in violation of insider trading laws. $727 \mathrm{~F}$ Supp at 1127. The court held that Elliot must forfeit his gross profits. He could deduct the commissions and interest on his margin loans as marginal costs-all legitimate marginal costs-but not his taxes, which were part of his overhead. Id at 112829.

In United States $v$ Riley, 78 F3d 367 (8th $\mathrm{Cir}$ 1996), the defendants used an insurance company to bribe state officials and defraud insurance regulators, a group health care insurance plan, and a podiatrists' association. Id at 369 . The court did not allow forfeiture of all proceeds. Id at 371 . The government could not seize premiums paid by policyholders because this would in effect forfeit the funds required to pay the legitimate marginal costs of providing these customers insurance. Id. Providing insurance is a legal transaction. The Eighth Circuit made this very point in Simmons to distinguish the outcome there from that in Riley. The court stated that the direct costs in Riley were paid to innocent policyholders, while in Simmons all payments were for illegal activities. Simmons, 154 F3d at 771.

${ }^{124}$ Moreover, that the proposed definition is a product of simple economic theory suggests that courts interpreting terms in the context of criminal fines should look to that theory for guidance. Economics can be a useful tool for statutory interpretation by providing a lens through which inconsistencies among courts can be reconciled.

${ }^{123}$ Saccoccia, 823 F Supp at 999.

${ }^{126}$ Id at 1006. Note that the district court found that three of the defendants each had to forfeit $\$ 136$ million because each of these defendants "reasonably could have foreseen" the receipt of $\$ 136$ million in proceeds under RICO conspiracy law. Id. 
erty transferred to foreign drug lords. In such cases, RICO authorizes seizure of substitute assets under Section 1963(d), but Saccoccia and his partners probably did not have $\$ 136$ million in substitute assets. ${ }^{127}$ These credit constraints are a foil to the optimal deterrence properties of the definition of "proceeds" discussed in Part II.

Moreover, even without credit constraints RICO forfeiture may not be a complete solution. If, due to the underdeterrence problem discussed in Part II, defendants continue to seek out racketeering opportunities after forfeiture, courts should prevent future crimes through punishments such as imprisonment. However, courts should be wary of going overboard. RICO authorizes a number of different penalties. These include criminal forfeiture of "proceeds" and "interests," criminal fines, and prison sentences. ${ }^{128}$ Furthermore, injured private parties can sue for civil forfeiture of defendants' interests in the offending RICO enterprise. ${ }^{129}$ If each of these penalties is implemented such that in isolation or in combination with a subset of others it is optimal, applying any of the remaining penalties may lead to overdeterrence.

Courts should also be wary of the constutitional constraints on forfeiture. Fortunately, the definition of proceeds this Comment advocates crosses none of these limits. The most obvious constitutional difficulty involved with forfeiture is the Eighth Amendment's prohibition on excessive fines. ${ }^{130}$ The Supreme

${ }^{127}$ Id at 999.

${ }^{128} 18$ USC $\$ 1963(a)$.

${ }^{129} 18$ USC $\$ 1964$.

${ }^{130}$ US Const, Amend VIII. Forfeiture faces two smaller constitutional risks. One is the First Amendment. If a forfeiture order requires confiscation of expressive materials, such as print or videos, defendants may attempt to invoke their free speech rights. The Supreme Court, in Alexander $v$ United States, 509 US 544 (1993), clearly held that RICO forfeiture is neither impermissible as a prior restraint on speech nor unconstitutionally overbroad. Alexander considered the case of a bookseller who was convicted of violating federal obscenity laws and RICO and ordered to forfeit his business and nearly $\$ 9$ million in racketeering proceeds. Id at 547-48. The defendant claimed that the forfeiture shut down his adult entertainment business and was, therefore, an unconstitutional prior restraint on speech. The Court rejected this argument and held that RICO is a permissible criminal punishment, not a prior restraint on speech. Id at 549-50. The forfeiture order does not prevent the defendant from engaging in any expressive speech. It only prevents him from financing those activities with assets derived from his prior racketeering activities. Id at 550-51. The Court also rejected the defendant's claim that RICO was overbroad. RICO does not criminalize constitutionally protected speech and forfeiture has no more of a "chilling" effect on free expression than threats of a prison term or a large fine, the alternative punishments under the RICO statute, both of which are constitutional. Id at 55556, citing Fort Wayne Books, Inc $v$ Indiana, 489 US 46, 60 (1989). Finally, the Court noted that "a contrary scheme would be disastrous from a policy standpoint, enabling racketeers to evade forfeiture by investing the proceeds of their crimes in businesses engaging in ex- 
Court laid out the test for whether forfeiture violates the Excessive Fines Clause in United States $v$ Bajakajian. ${ }^{131}$ The Court held that a punitive forfeiture violates the Eighth Amendment if it is grossly disproportionate to the gravity of the offense. ${ }^{132}$

The proceeds forfeiture rule proposed here passes this test. Defining proceeds as greater than gross profits but less than total revenues is not grossly disproportionate to the gravity of a RICO offense. Bajakajian involved a defendant who attempted to export $\$ 360,000$ in cash without reporting it to customs. ${ }^{133}$ The government wanted to seize the entire amount-punishment akin to forfeiture of total revenues in the RICO context. ${ }^{134}$ The Court held that the government's request would violate the Eighth Amendment, but specifically stated that it was not passing judgment on whether an amount less than total revenues would be grossly disproportionate. ${ }^{135}$ Moreover, the Court found the offense in $\mathrm{Ba}$ jakajian insufficiently grave to justify total revenue seizure because it was "unrelated to any other illegal activities." 136 However one defines forfeiture in the RICO context, it is related to illegal activities. At the very least this logic supports forfeiture of net profits plus illegitimate marginal costs. In Bajakajian, the Court invalidated a forfeiture that was more severe than the forfeiture rule advocated here and that was punishment for a crime that was less severe. ${ }^{137}$

pressive activity." Alexander, 509 US at 552.

The second risk from forfeiture concerns the due process and equal protection guarantees of the Fifth and Fourteenth Amendments. Judge Van Graafeiland in his Lizza dissent argued that forfeiture of taxes penalizes the defendant who pays taxes more than the one who does not, even if both commit the same offense. Lizza, 775 F2d at 499 (Van Graafeiland dissenting), citing Skinner v Oklahoma, 316 US 535, 541 (1942) (noting the government should not lay "an unequal hand on those who have committed intrinsically the same quality of offense"). The problem with this claim is that the two defendants do not commit precisely the same act. Payment of taxes by a criminal enterprise may indicate that it has infiltrated a legitimate business. Requiring forfeiture of tax payments, then, punishes racketeering activity in the context of a legitimate business more than such activity in isolation. Moreover, the law, both purposely and due to chance, often punishes identical acts differently. In the law of attempts, two individuals with the same actus reus may be punished differently if one person's attempt is successful, while the other's is not. More generally, even if both individuals are successful, the law may fail to punish one if she is not apprehended or prosecuted due to limited resources.

${ }^{131} 524$ US 321, 118 S Ct 2028 (1998).

$132118 \mathrm{~S} \mathrm{Ct}$ at 2036.

${ }^{133}$ Id at 2032 . 31 USC $\S 5316(a)(1)(A)$ (1994) requires reporting the export of any "monetary instruments of more than $\$ 10,000$."

${ }^{13}$ Bajakajian, $118 \mathrm{~S}$ Ct at 2032. Actually, an argument could be made that the court was talking about total asset forfeiture, suggesting a possible problem with Section 1963(a)(1) and (2), but not (3).

iss Id at $2038 \mathrm{n} 11$.

${ }^{136}$ Id at 2038.

${ }^{137}$ That the Bajakajian Court found total revenue forfeiture to be an excessive fine 
The Bajakajian Court indicated that it chose a gross rather than strict proportionality rule because judgment about what offense to punish and "the appropriate punishment for an offense belong in the first instance to the legislature." ${ }^{138}$ The Court seems to suggest that legislative judgments should be granted a good deal of deference when courts determine whether a punishment is proportional to an offense. Congress passed RICO to slow the infiltration of organized crime into legitimate business, ${ }^{139}$ an aim the forfeiture of overhead advances. Moreover, Congress stated that the government may seek forfeiture of overhead to alleviate evidentiary burdens on prosecutors. ${ }^{140}$ The legislative history behind RICO provides plausible justifications for forfeiting overhead and illegitimate marginal costs in response to a RICO violation and demonstrates a reasonable legislative judgment that such forfeiture is not a disproportionate punishment. Courts should defer to this judgment.

Finally, remedial fines are exempt from a proportionality analysis because they compensate society for a loss. ${ }^{141}$ At least one court has argued that while interests forfeiture under Section 1963(a)(1)-(2) may be punitive, proceeds forfeiture under Section 1963(a)(3) is remedial. ${ }^{142}$ In fact, the Bajakajian dissent actually described the money to be forfeited in that case as "proceeds" in its attempt to characterize the forfeiture as a remedial one, and it

suggests that the definition of proceeds forfeiture here can be defended against arguments that total revenue forfeiture is more appropriate by appealing to the canon of constitutional avoidance. See Ashwander v Tennessee Valley Authority, 297 US 288, 341 (1936) (Brandeis concurring). Given that a gross profits plus illegitimate marginal costs forfeiture is less severe than a total revenues forfeiture, it is less likely to contravene the Excessive Fines Clause.

${ }^{138}$ Bajakajian, $118 \mathrm{~S}$ Ct at 2037.

${ }^{130}$ Russello $v$ United States, 464 US 16, 27-28 (1983); United States v Turkette, 452 US 576, 591 (1981).

${ }^{100} \mathrm{~S}$ Rep No 98-225 at 199 (cited in note 18).

"Bajakajian, $118 \mathrm{~S}$ Ct at 2034.

${ }^{142}$ United States v Alexander, 32 F3d 1231, 1236 (8th Cir 1994), cert denied, 118 S Ct 180 (1997) (" $[$ O]ther courts have recognized the distinction in the RICO forfeiture statutes between the proceeds from the racketeering activity and property which facilitates or affords a defendant with a source of influence over the illegal enterprise. . . Forfeiture of proceeds cannot be considered punishment, and thus, subject to the excessive fines clause, as it simply parts the owner from the fruits of the criminal activity."), citing United States $v$ Sarbello, 985 F2d 716, 723 (3d Cir 1993), and Austin v United States, 509 US 602, 622 n 14 (1993). See also Hurley, $63 \mathrm{~F} 3 d$ at 21 (arguing that total revenue is some measure of the total harm to society from the offense).

It should be noted that Alexander is the only appellate case that has considered whether forfeiture under RICO Section 1963 violates the Excessive Fines Clause of the Eighth Amendment. While it was decided before Bajakajian, it did find that "grossly disproportionate" is the proper test for excessive fines, but held that because proceeds forfeiture-as opposed to interests forfeiture-was remedial, it was exempt from the excessive fines analysis. Alexander, 32 F3d at 1236. 
pointed out that "[a]s a rule, forfeitures of criminal proceeds serve the nonpunitive ends of making restitution to the rightful owners and of compelling the surrender of property held without right or ownership." "143 If one-quite plausibly-interprets the forfeiture in Bajakajian not as proceeds forfeiture but as asset or interest forfeiture, then even the majority's narrow holding is not inconsistent with categorizing Section 1963(a)(3) as remedial.

\section{CONCLUSTON}

Section 1963(a)(3), added to the RICO statute by the 1984 amendments, authorizes the criminal forfeiture of "proceeds" obtained by the defendant. "Proceeds" is not defined in the statute, and its meaning under a plain textual reading is unclear. Careful analysis of the legislative history apparently excludes "net profits" as a possible interpretation but fails to distinguish among the remaining alternatives.

This Comment advocates an interpretation of proceeds that would allow the government to seek forfeiture of something between total revenues and total revenues minus marginal costs. At trial, courts should allow defendants to prove and deduct any legitimate marginal costs for which the government has failed to account. If they cannot prove legitimate marginal costs, then total revenues will be subject to forfeiture. The resulting forfeiture alleviates accounting burdens on prosecutors, reduces the overall level of racketeering activity, and protects innocent third party suppliers-all without any constitutional impediment.

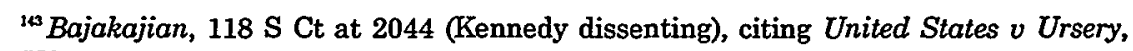
518 US 267, 284 (1996). 